\title{
Theoretical Research of High Quality Teaching for Higher Education
}

\author{
Yaoxi Chen \\ Xijing University, Xi'an, China \\ 365317084@qq.com
}

\begin{abstract}
Keywords: Higher education; Quality of teaching; Professional education; System theory
\end{abstract}
\begin{abstract}
Higher education is established on the basis of general education of professional education. In the basic principles of education, education and teaching process higher education is consistent with ordinary education. The quality assurance of higher education is a planned and systematic activity. The quality assurance of higher education according to the need to implement. In this article, the research content of higher education has been introduced; Concept of higher education quality assurance is described; Theory of higher education quality assurance is studied. Higher education quality assurance is a practice field. Higher education quality assurance theory should include education evaluation theory, total quality management theory, system science theory. Finally, points out that to improve the level of the higher education system elements are of great significance, for the quality of higher education teaching. Affecting the key link of teaching quality, it is an effective way to improve the quality of higher education.
\end{abstract}

\section{Introduction of Higher Education}

Higher education refers to all established on the basis of general education of professional education. Higher education includes the special course, the graduate and undergraduate, full-time and part-time, face-to-face and non face-to-face, school and the school form and so on in the form of levels and forms. China's higher education, there is a college, university and college and graduate school and the university of the worker, and so on. Higher education in general is a full-time institution of higher learning education, especially in university and college undergraduate education as the main research object, and also deals with other forms of hierarchy and appropriately.

Higher education with general education, in the basic principles of education, education and teaching process is consistent with the basic law. But as a result of higher education is based on common cultural science knowledge of professional education, cultivate the superstructure and the economic departments of higher specialized talents. Higher education object of education is generally young college students [1]. College students' physical and mental development characteristics is different from primary and middle school students, and so on. Therefore, higher education and common education is different, must be some special rules. For example: the teaching content of institutions of higher learning is the basis of the necessary professional knowledge and skills. The teaching method should adapt to college students' physical and psychological characteristics [2]. Scientific research become an organic part in the teaching process and important functions of the school. About the methods of moral education, the responsibility and mission of the university teachers, university and college leadership and management, etc., there are also different in the implementation of the general education of primary and secondary schools.

The research content of higher education, mainly include: the basic concept of higher education; The status and role of higher education, as well as its relationship with politics, economy, culture science; Institutions of higher learning professional training objectives; The characteristics of the college students' physical and mental development; The task of university teachers and training to improve; The law of education and teaching process; The content of moral education, intellectual education, physical education and the method; Scientific research; Higher education system; Leading system of institutions of higher learning and management methods and so on. 


\section{Quality Assurance of Higher Education}

Higher education to introduce the concept of quality assurance, is to "make educators and education to build a mutual trust relationship between the service object, hence leading to the sustainable development of the school. Through quality management, quality supervision, quality control, quality audit, quality certification and quality assessment of a variety of means, guarantee and promote the colleges and universities to improve the quality of education.

British higher education quality assurance department experts believe that higher education quality assurance is the quality assurance agency according to certain quality standard system, according to certain procedures, review and assessment of the quality of education in colleges and universities in order to guarantee the quality of higher education to the society." To give priority to with certification countries, this definition is not comprehensive [3]. In addition, the definition of the key in the external quality assurance, to pay attention to internal quality assurance. Chinese scholars Xiong Zhixiang to perfect the definition of higher education quality assurance [4]. He said: "the quality of the institutions of higher education on the basis of certain systems and procedures, in the internal quality management, quality supervision and self assessment, on the basis of accepting peer experts to the quality of the education evaluation, audit and certification." This definition to the concept of higher education quality assurance as a complete system, in this definition, the concept of higher education quality assurance involves eight major:

(1) Quality system. Quality system is the basis of the quality assurance, is refers to the higher education quality assurance in order to ensure to implement the required sum of organization structure, procedures, processes and resources.

(2) Quality policy. Quality policy is to point to will be released to the overall quality of purpose, standards, and school direction, is an important part of the goal of higher education, is to promise the quality of government, society and students, is also the guide of all departments and disciplines within the school and the teachers and students staff.

(3) Quality management. Quality management refers to according to determine the quality policy to implement quality control and improvement of all management activity, is the core of university internal quality assurance.

(4) Quality supervision. Quality supervision, an important part of the university internal quality assurance, of the state of the university education is the continuous monitoring and analysis.

(5) Self-assessment. Self assessment of their own education quality in colleges and universities the measure of value judgment, general situation and construction of disciplines involved in college education and management, is not only the importance of university internal quality assurance measures, is also an important part of the external quality assurance and composition.

(6) Quality certification. Quality certification on the basis of school self-evaluation and peer evaluation, according to a certain gain social acceptance in the eligibility criteria whole managerial level, level of disciplines in colleges and universities to confirm. The government's role of quality certification mainly reflected on the recognition of accrediting agency, this approach effectively mobilized the university autonomy and self-discipline.

\section{Study of Theory for Quality Assurance}

Higher education quality assurance is an emerging field of research and practice of involving theory is very extensive, including education evaluation theory, total quality management theory, system science theory to its influence.

Education Evaluation Theory. Education evaluation is a major means of higher education quality assurance. Education evaluation theory development up to now, has experienced from a subjective evaluation to measure to the development of science and the evaluation process. At present, there are 10 main representative of education evaluation theory [5]. Objective evaluation, such as: behavior decision-making evaluation, system analysis and evaluation, the goal of free evaluation, response evaluation, interpretation evaluation, evaluation of CSE, cost - effect analysis and evaluation, 
the fourth generation of education evaluation, modern education evaluation theory. Education evaluation is a reference to the existing education goal, through the system to collect information, take a scientific approach to people and things in education activities in the process of comprehensive value analysis, and judgment.

Total Quality Management Theory. Total quality management is a kind of became popular in the early $1960 \mathrm{~s}$, modern quality management methods. Range of quality management, from design to sales and service of all factors affecting the quality of each part. Participation and the quality management is the management of the whole work process. Total quality management theory for the development of higher education quality assurance activities greatly [6]. Higher education mainly from the following several aspects to reference and application of total quality management:

(1)Higher education quality management is a process of constant pursuit of excellence in colleges and universities, is the focus of the higher education quality management of higher school education teaching quality continuous improvement, this requires implementation of total quality management, full and comprehensive.

(2)Output of higher education is not only knowledge, more output, colleges and universities' satisfaction with the demand for social education teaching activities is the essence of the concept of higher education quality, so colleges must strengthen self-discipline consciousness, avoid the blindness and short-term behavior.

(3) Higher education quality assurance is a dynamic spiral cycle[7]. In this process, the government, society, colleges and universities based on the current social development, the demand for talent that is the goal of education quality, education teaching activities of college management, control and evaluation. Higher education quality assurance is a mostly within outside, inside and outside combination, promote the organic whole. Colleges and universities is the main part of the internal quality assurance, and the government and society is the main body of external quality assurance.

System Science Theory. System as the research object, carries on the discussion and to produce new scientific theories. Including system theory, information theory, cybernetics, mutation theory, the dissipative structure theory, synergy theory and so on [8]. Discipline system is made up of these theories become scientific system.

Improve the quality of higher education, it is necessary to improve the level of all the elements of higher education system. Elements affecting the quality of the key link, set up to prevent degradation of long-term mechanism, is the effective way to improve the quality of higher education.

(1) Systematically. Higher education is a subsystem of social system, government and society should establish the corresponding mechanism system of institutions of higher learning shoulder the responsibility, to improve the quality of education and supervision; And higher education is a relatively independent academic system, made up of different types of higher education subsystem, in its work consciously and actively integrated into the society, at the same time, must follow the rules of the development of education itself and the basic characteristics of academic organization [9].

(2) Level. To the hierarchy of system is based on the analysis of the system of the longitudinal level sex, both inspection system different levels level of generality, to discover its personality more. The different levels of higher education system structure to the development of higher education system play a different function, therefore, to guide all sorts of different levels and types of the coordinated development of higher education, it should establish different quality evaluation system and evaluation standard.

(3)Integrity. Higher education quality assurance process is a continuous improvement cycle [10]. Among them, the "plan" is the general idea of the quality security, planning is to determine the quality objectives and achieve the goal of process; "Execution" is the management in the process of quality guarantee implementation of the organization, command, coordination, control, and a series of management function, according to the requirement of the quality objectives to set up the quality system, perfect the system, resources allocation, implementation, maintenance, coordination, education incentive, etc.; "Check" is the control function of management, establish feedback mechanism, provide feedback, check whether the quality system is effectively to meet the 
requirements of the quality objectives; "Processing" was based on the quality of the scale, the deficiencies for correction and adjustment in the management, to further improve the quality system.

\section{Conclusion}

Total quality management theory for the development of higher education quality assurance activities greatly. In the basic principles of education, education and teaching process on the basic law of higher education is consistent with ordinary education. The quality assurance of higher education is in a planned and systematic activities. The quality assurance of higher education according to the need to implement. In this article, the research content of higher education have been introduced; The concept of higher education quality assurance is described; Higher education quality assurance theory is studied. Higher education quality assurance is a practice field. Higher education quality assurance theory should include education evaluation theory, total quality management theory, system science theory. Finally, points out that to improve the level of the higher education system elements is of great significance, for the quality of higher education teaching. Affecting the key link of teaching quality, it is an effective way to improve the quality of higher education.

\section{References}

[1] J.B.Wang, H.T.Yang: New Field of Overseas Investment-New Trend of Transnational Higher Education (DongYue Review, China, 2012)

[2] G.S.Yi: University Chinese-Foreign Cooperation in Running Schools Mode and Operation Mechanism of Research (Shanghai University Publishing House, China 2007.)

[3] B.C.Ji:Our Country's Higher Education Scale Forecast Analysis in 2020, Vol. 1 (2011) No. 1, p. 305.

[4] Verbik L, Merkley C: Intematinal Branch Campus - Models and Trends, Observatory on Borderless (Higher Education Report, China, 2006).

[5] L.J.Guo: Under Globalization of Transnational Higher Education -Point of View, Problems and China's Response (China Social Sciences Press, China, 2009)

[6] H.Y.Liu: U DP Proportion Higher Education and Social Policy Research, Vol. (2012), P. 27-28.

[7] Benoit Minogue: Higher Education Spending and Output-Complexity of Relationship, Peking University Education review, Vol. 2 (2013), 60.

[8] Henry m. levin. Education How to Adapt to Future-Background of American Education, Peking University Education Review, Vol. 2 (2013), p. 2-3.

[9] Y.L.Xie: Soul of European Universities Classification, Comparative Education Research, Vol.4 (2010), p. 45.

[10] G.P.Feng: Transnational Education-International Comparative Study (Shanghai People's Publishing House, China, 2010) 